Article

\title{
Design and Characterization of a Novel Artificial Peroxidase
}

\author{
Ye Yuan ${ }^{1}$, Jia Xu ${ }^{1}$, Zhenyu Zhao ${ }^{1}$, Hui Li ${ }^{1}$, Kai Wang ${ }^{1}$, Zhi Wang ${ }^{1,2,3, *}$ and Liping Wang ${ }^{1,2,3, *}$ \\ 1 School of Life Sciences, Jilin University, Changchun 130012, China; yeyuan18@mails.jlu.edu.cn (Y.Y.); \\ xujia16@mails.jlu.edu.cn (J.X.); zhenyu18@mails.jlu.edu.cn (Z.Z.); lihui18@mails.jlu.edu.cn (H.L.); \\ wangkai17@mails.jlu.edu.cn (K.W.) \\ 2 Key Laboratory for Molecular Enzymology and Engineering, the Ministry of Education, Jilin University, \\ Changchun 130012, China \\ 3 Engineering Laboratory for AIDS Vaccine, Jilin University, Changchun 130012, China \\ * Correspondence: wangzhi@jlu.edu.cn (Z.W.); wanglp@jlu.edu.cn (L.W.); \\ Tel.: +86-431-8518-2281 (Z.W.); +86-431-8515-5348 (L.W.)
}

Received: 18 January 2019; Accepted: 7 February 2019; Published: 11 February 2019

check for updates

\begin{abstract}
In this study, we reported on a novel mimetic peroxidase, deuterohemin-Ala-His-Glu, (Dh-A-H-E). The kinetic parameters of Dh-A-H-E suggested that it was a mimetic peroxidase and followed the ping-pong mechanism. Compared to horseradish peroxidase, Dh-A-H-E exhibited excellent stability when tested at different $\mathrm{pH}$ and temperatures, and using different organic solvents. Based on our above results, a new method using Dh-A-H-E has successfully been developed for the fast and quantitative detection of trace amounts of glucose.
\end{abstract}

Keywords: Dh-A-H-E; mimetic peroxidase; kinetics; catalytic activity; stability; glucose detection

\section{Introduction}

Horseradish peroxidase (HRP) is a naturally occurring enzyme that has been widely applied in organic synthesis and biotransformation [1]. For example, it has been successfully used as a bleaching detergent. It can activate hydrogen peroxide and convert the nonluminescent substrate, 3,3',5,5'-tetramethylbenzidine (TMB), into a luminescent product, oxidized TMB (oxTMB). This application of HRP has been used for analytical diagnostics [2,3]. Furthermore, HRP can be used in many small-scale organic reactions, including oxidative coupling [4], selective hydroxylation [5], and oxygen-transfer reactions [6]. However, high temperatures, harsh $\mathrm{pH}$ conditions, and a number of chemical compounds can denature HRP easily, which severely limits its extensive application [7-9]. Owing to the limitations on reaction conditions, many efforts have been made to find, or design, a new artificial enzyme to mimic HRP. In the past decades, many small molecule analogs (fluorescein [10], ferrocene [11], etc.), and nanomaterials (Au nanoclusters [12], cobalt incorporated mesoporous silica nanomaterials [13], etc.) have been reported to have peroxidase-like activity. However, the majority of these reported enzyme mimics possess only poor peroxidase activity.

As a kind of peroxidase mimic, Heme-peptide has been researched for years because it is highly stable and can be easily synthesized. Heme-peptides are produced by covalently linking peptides to ferriporphyrin and have shown great potential for use in medical detection, as biocatalysts, sensitive sensors, and in other applications [14-16]. Microperoxidases (MPs) have been the most effective peroxidases among these heme-peptides. Several MPs have been previously characterized, such as microperoxidase-11 (MP-11), microperoxidase-9 (MP-9), and microperoxidase-8 (MP-8). Owing to their high peroxidase activity, external stability, and structural consistency, MPs have been used in many applications. However, the chemical synthesis of MP-11 has proven difficult [17]. 
We chemically synthesized the catalytically active center, comprising of deuterohemin (Dh) linked to alanine and histidine, according to a published method [18,19]. When glutamic acid (E) was linked to the catalytically active center to generate $\mathrm{Dh}-\mathrm{A}-\mathrm{H}-\mathrm{E}$, it was found that this new heme-peptide could efficiently catalyze TMB in the presence of $\mathrm{H}_{2} \mathrm{O}_{2}$ (Scheme 1). In addition, the catalytic properties of $\mathrm{Dh}-\mathrm{A}-\mathrm{H}-\mathrm{E}$ were investigated. Another important advantage of $\mathrm{Dh}-\mathrm{A}-\mathrm{H}-\mathrm{E}$ is that its optimal $\mathrm{pH}$ is 7.4 and it can exhibit high peroxidase activity at $\mathrm{pH} 7.0$, which can dramatically simplify the procedure of glucose detection [20-22]. Thus, an improved method for detecting trace amounts of glucose using Dh-A-H-E was developed.<smiles>Cc1cc(-c2cc(C)c(N)c(C)c2)cc(C)c1N</smiles>

TMB

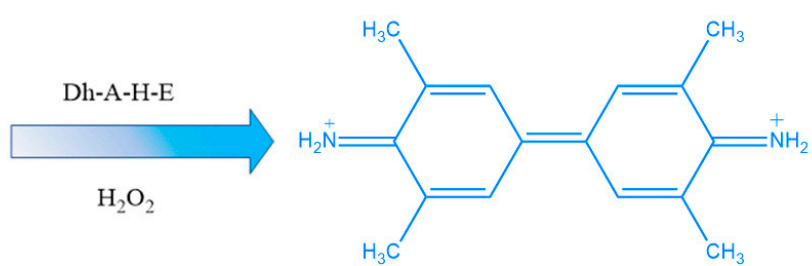

oxTMB

Scheme 1. Catalytic reaction of deuterohemin-Ala-His-Glu (Dh-A-H-E).

\section{Results and Discussion}

\subsection{The Peroxidase Activity of Deuterohemin-Ala-His-Glu (Dh-A-H-E)}

To evaluate the catalytic activity of $\mathrm{Dh}-\mathrm{A}-\mathrm{H}-\mathrm{E}$ as a mimetic peroxidase, TMB was mixed with Dh-A-H-E in the presence of $\mathrm{H}_{2} \mathrm{O}_{2}$. As shown in Figure 1, solutions containing TMB and low concentrations of Dh-A-H-E were almost colorless, while the solution of TMB and $\mathrm{H}_{2} \mathrm{O}_{2}$ was slightly blue. When we mixed $\mathrm{Dh}-\mathrm{A}-\mathrm{H}-\mathrm{E}, \mathrm{TMB}$, and $\mathrm{H}_{2} \mathrm{O}_{2}$ together for $5 \mathrm{~min}$, a blue solution was obtained, and a strong characteristic absorption peak of oxidized TMB (oxTMB) was observed at $652 \mathrm{~nm}$. These results indicated that $\mathrm{Dh}-\mathrm{A}-\mathrm{H}-\mathrm{E}$ had peroxidase activity.

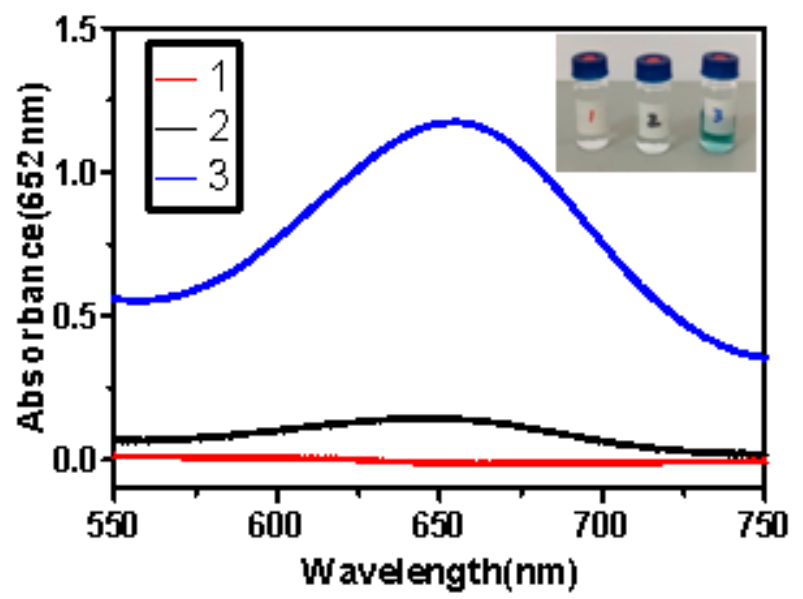

Figure 1. UV absorption of (1) Dh-A-H-E + 3,3',5,5'-tetramethylbenzidine (TMB), (2) $\mathrm{TMB}+\mathrm{H}_{2} \mathrm{O}_{2}$, and (3) $\mathrm{Dh}-\mathrm{A}-\mathrm{H}-\mathrm{E}+\mathrm{TMB}+\mathrm{H}_{2} \mathrm{O}_{2}$. 


\subsection{Optimizing the Reaction Conditions}

Temperature and $\mathrm{pH}$ can influence the catalytic activity of peroxidases, including HRP and other peroxidase mimics $[23,24]$. Thus, to determine the optimal reaction conditions for the peroxidase activity of $\mathrm{Dh}-\mathrm{A}-\mathrm{H}-\mathrm{E}$, we tested a variety of experimental conditions. The relationship between the temperature and catalytic activity of $\mathrm{Dh}-\mathrm{A}-\mathrm{H}-\mathrm{E}$ is shown in Figure 2a, with the optimal temperature for Dh-A-H-E activity occurring at $25^{\circ} \mathrm{C}$. The optimal $\mathrm{pH}$ for $\mathrm{Dh}-\mathrm{A}-\mathrm{H}-\mathrm{E}$ catalytic activity was 7.4 and the effect of $\mathrm{pH}$ on activity is shown in Figure $2 \mathrm{~b}$.

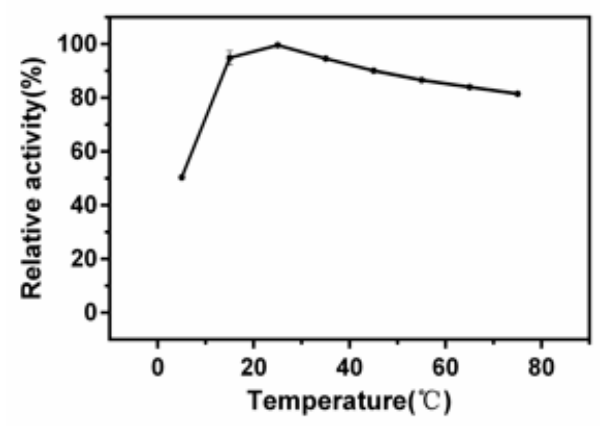

(a)

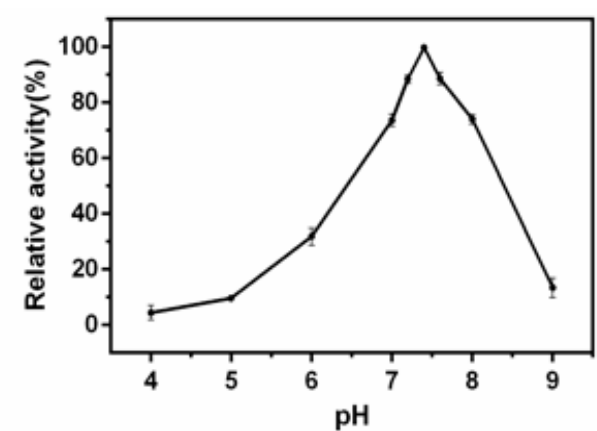

(b)

Figure 2. Effect of temperature and $\mathrm{pH}$ on the catalytic activity of $\mathrm{Dh}-\mathrm{A}-\mathrm{H}-\mathrm{E}$. (a) The reaction was carried out at different temperatures $\left(5-75^{\circ} \mathrm{C}\right)$ and the peroxidase activity of Dh-A-H-E was measured according to the standard assay in Section 3.3. (b) The reaction was carried out under various $\mathrm{pH}$ levels (4-9) and the peroxidase activity of Dh-A-H-E was measured according to the standard assay in Section 3.3. The catalytic activity at $\mathrm{pH} 7.4$ and $25{ }^{\circ} \mathrm{C}$ is taken as $100 \%$, and experiments were performed in triplicate to obtain the mean value.

\subsection{Kinetics}

To further characterize the catalytic ability of $\mathrm{Dh}-\mathrm{A}-\mathrm{H}-\mathrm{E}$, the reaction rates under different conditions were measured across various substrate concentrations corresponding to the Michaelis-Menten curves for both $\mathrm{H}_{2} \mathrm{O}_{2}$ (Figure 3a) and TMB (Figure 3b). Double-reciprocal plots were generated to analyze the kinetic parameters with $\mathrm{H}_{2} \mathrm{O}_{2}$ and TMB (Figure 3c,d). From Table 1, the $\mathrm{Km}$ (the Michaelis constant, representing the affinity of the enzyme for the substrate) of Dh-A-H-E was calculated to be $0.27 \mathrm{mM}$ for $\mathrm{H}_{2} \mathrm{O}_{2}$ and $0.20 \mathrm{mM}$ for TMB. The Kcat (the turn number) of Dh-A-H-E was calculated to be $2.37 \mathrm{~s}^{-1}$ for $\mathrm{H}_{2} \mathrm{O}_{2}$ and $2.10 \mathrm{~s}^{-1}$ for TMB. The catalytic efficiency (Kcat $/ \mathrm{K} m$ ) of $\mathrm{Dh}-\mathrm{A}-\mathrm{H}-\mathrm{E}$ was measured to be $8.78 \times 10^{2} \mathrm{~s}^{-1} \cdot \mathrm{M}^{-1}$ for $\mathrm{H}_{2} \mathrm{O}_{2}$ and $1.05 \times 10^{3} \mathrm{~s}^{-1} \cdot \mathrm{M}^{-1}$ for TMB. These data indicated that $\mathrm{Dh}-\mathrm{A}-\mathrm{H}-\mathrm{E}$ had both a high affinity and a high catalytic activity.

Table 1. The catalytic efficiency of Dh-A-H-E.

\begin{tabular}{|c|c|c|c|c|c|c|}
\hline \multirow[b]{2}{*}{ Catalyst } & \multicolumn{3}{|c|}{ Substrate (TMB) } & \multicolumn{3}{|c|}{ Substrate $\left(\mathrm{H}_{2} \mathrm{O}_{2}\right)$} \\
\hline & $\begin{array}{c}\mathrm{Km} \\
(\mathrm{mM})\end{array}$ & $\begin{array}{l}\text { Kcat } \\
\left(\mathrm{s}^{-1}\right)\end{array}$ & $\begin{array}{l}\mathrm{Kcat} / \mathrm{Km} \\
\left(\mathrm{s}^{-1} \cdot \mathrm{M}^{-1}\right)\end{array}$ & $\begin{array}{c}\mathrm{Km} \\
(\mathrm{mM})\end{array}$ & $\begin{array}{l}\text { Kcat } \\
\left(\mathrm{s}^{-1}\right)\end{array}$ & $\begin{array}{c}\mathrm{Kcat} / \mathrm{Km} \\
\left(\mathrm{s}^{-1} \cdot \mathrm{M}^{-1}\right)\end{array}$ \\
\hline $\mathrm{Dh}-\mathrm{A}-\mathrm{H}-\mathrm{E}$ & 0.20 & 2.10 & $1.05 \times 10^{3}$ & 0.27 & 2.37 & $8.78 \times 10^{2}$ \\
\hline
\end{tabular}




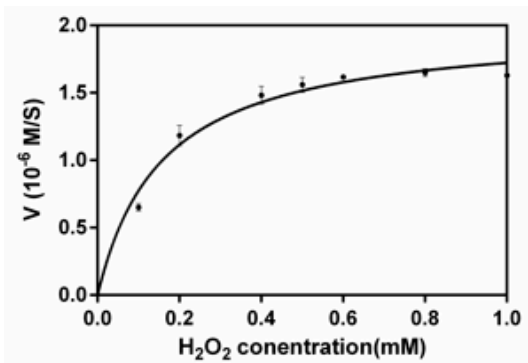

(a)

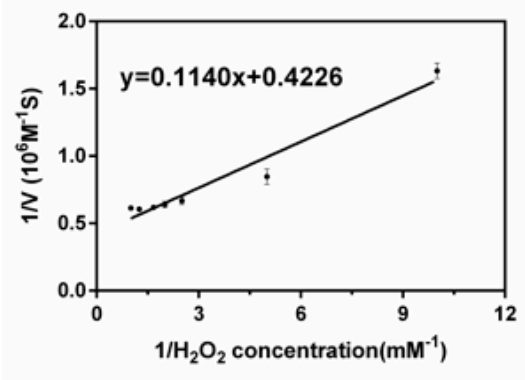

(c)

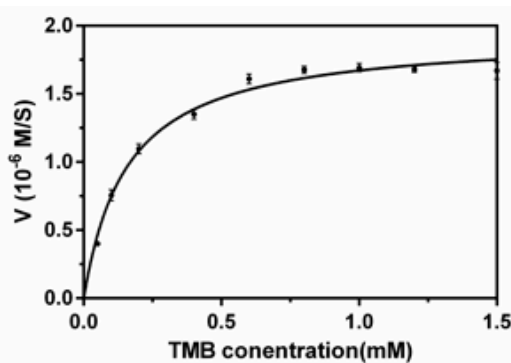

(b)

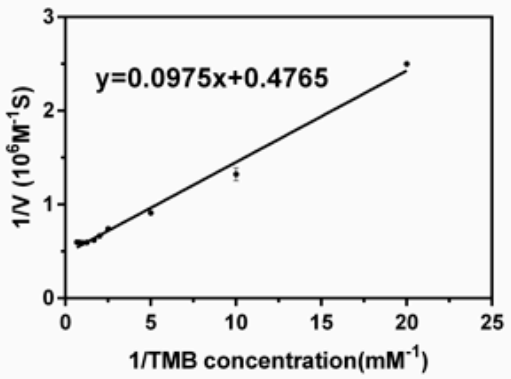

(d)

Figure 3. Kinetics assay of Dh-A-H-E. (a) Michaelis-Menten curves against $\mathrm{H}_{2} \mathrm{O}_{2}$ concentration, in which the concentration of TMB was fixed at $2.0 \mathrm{mM}$; (b) Michaelis-Menten curves against TMB concentration, in which the concentration of $\mathrm{H}_{2} \mathrm{O}_{2}$ was fixed at $1.0 \mathrm{mM}$; (c) double-reciprocal curves against $\mathrm{H}_{2} \mathrm{O}_{2}$, in which the concentration of TMB was fixed at $2.0 \mathrm{mM}$; and (d) double-reciprocal curves against TMB, in which the concentration of $\mathrm{H}_{2} \mathrm{O}_{2}$ was fixed at $1.0 \mathrm{mM}$. Experiments were performed in triplicate to obtain the mean value.

\subsection{Catalytic Mechanism}

Analysis of the reaction mechanism was conducted by varying the concentrations of $\mathrm{H}_{2} \mathrm{O}_{2}$ and TMB (Figure 4a,b). A set of fixed TMB concentrations was chosen, and the concentration of $\mathrm{H}_{2} \mathrm{O}_{2}$ was varied at each TMB concentration. The data were plotted in double-reciprocal form, which provided a series of apparently parallel lines. A series of parallel lines could also be observed by re-plotting the data with TMB as the variable substrate. Just like the natural HRP [25], the linearity of the double-reciprocal plots for both the $\mathrm{H}_{2} \mathrm{O}_{2}$ and TMB preparations strongly supported a ping-pong mechanism.

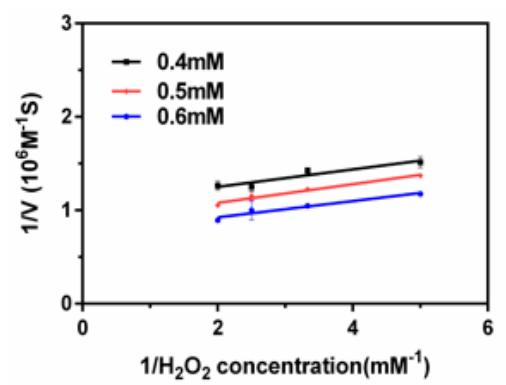

(a)

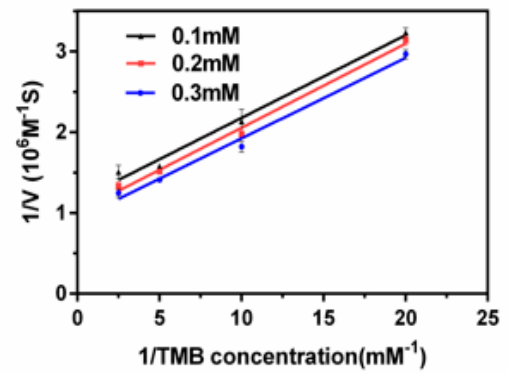

(b)

Figure 4. (a) Double-reciprocal plots at different $\mathrm{H}_{2} \mathrm{O}_{2}$ concentrations, in which the concentration of TMB was fixed at $0.4,0.5$, and $0.6 \mathrm{mM}$; (b) double-reciprocal plots at different TMB concentrations, in which the concentration of $\mathrm{H}_{2} \mathrm{O}_{2}$ was fixed at $0.1,0.2$, and $0.3 \mathrm{mM}$. Experiments were performed in triplicate to obtain the mean value. 


\subsection{Stability of $D h-A-H-E$}

The stability of Dh-A-H-E is crucial for extending its potential applications. In this study, $\mathrm{Dh}-\mathrm{A}-\mathrm{H}-\mathrm{E}$ was pre-incubated for $2 \mathrm{~h}$ at different $\mathrm{pH}$ and temperatures, and using different organic solvents. Then, we examined the residual activity of $\mathrm{Dh}-\mathrm{A}-\mathrm{H}-\mathrm{E}$ to evaluate its stability. $\mathrm{Dh}-\mathrm{A}-\mathrm{H}-\mathrm{E}$ retained over $70 \%$ of its activity following a $2 \mathrm{~h}$ incubation at $\mathrm{pH} 4.4-9.4$ for $2 \mathrm{~h}$, as shown in Figure $5 \mathrm{a}$. After a $2 \mathrm{~h}$ incubation at different temperatures, Dh-A-H-E retained $>95 \%$ of its baseline activity (Figure $5 \mathrm{~b}$ ). The residual activity of Dh-A-H-E after a $2 \mathrm{~h}$ incubation with organic solvents (DMSO, acetone, and acetonitrile) was $>38 \%$ of the baseline activity (Figure $5 \mathrm{c}$ ). By contrast, HRP had little catalytic activity in organic solvents or at high temperatures [26]. Another important advantage of $\mathrm{Dh}-\mathrm{A}-\mathrm{H}-\mathrm{E}$ is that it retains its catalytic activity even after storage in an aqueous solution for 3 months (Figure 5d). These results demonstrated that Dh-A-H-E had excellent stability and was very suitable for real-life applications.

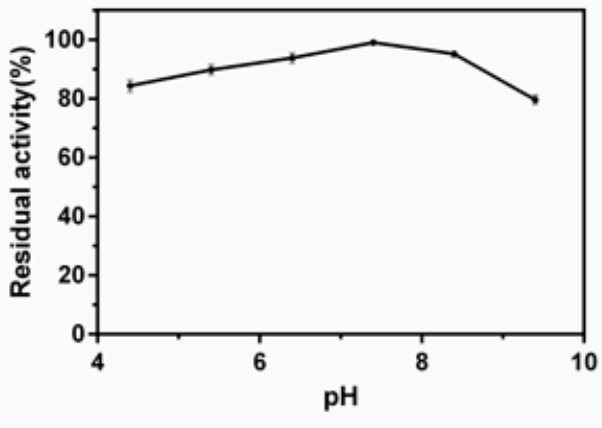

(a)

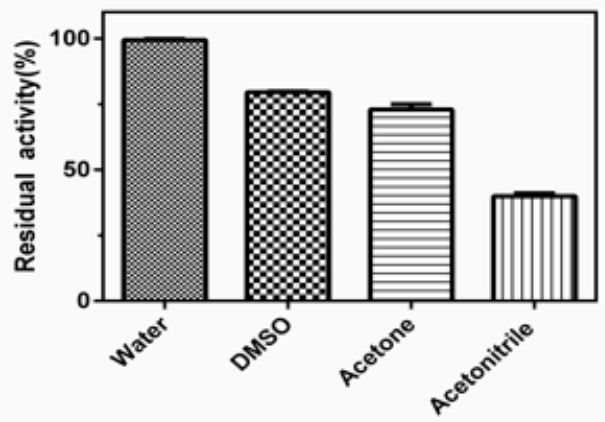

(c)

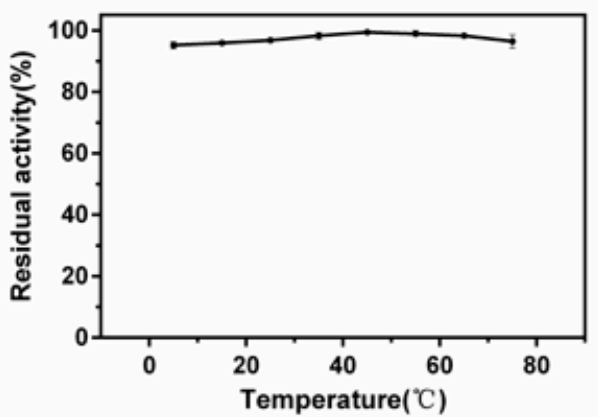

(b)

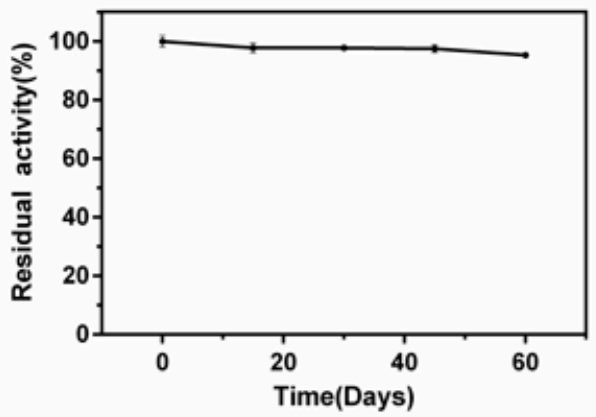

(d)

Figure 5. Stability of Dh-A-H-E. (a) Dh-A-H-E was incubated at a range of $\mathrm{pH}$ values from 4.4 to 9.4 for $2 \mathrm{~h}$, and then the residual activity was measured according to the standard assay in Section 3.3; (b) Dh-A-H-E was incubated at a range of temperature values from 5 to $75^{\circ} \mathrm{C}$ for $2 \mathrm{~h}$, and then the residual activity was measured according to the standard assay in Section 3.3; (c) Dh-A-H-E was incubated with different organic solvents (DMSO, acetone, and acetonitrile), and then the residual activity was measured according to the standard assay in Section 3.3; and (d) Dh-A-H-E was stored in an aqueous solution for a certain number of days, then the residual activity was measured according to the standard assay in Section 3.3. Experiments were performed in triplicate to obtain the mean value.

\subsection{Application of Dh-A-H-E for $\mathrm{H}_{2} \mathrm{O}_{2}$ and Glucose Detection}

On the basis of the above results, we developed a sensitive and simple system for detecting the trace amounts of $\mathrm{H}_{2} \mathrm{O}_{2}$ glucose by Dh-A-H-E (Figure 6a). A good linear relationship between the absorbance at $652 \mathrm{~nm}$ and the concentration of $\mathrm{H}_{2} \mathrm{O}_{2}$ can be observed in Figure 6a. The detection limit was in the range of $2.0-75 \mu \mathrm{M}$, and the linear regression equation was $\mathrm{A}=0.0160 \mathrm{C}+0.0706$ $\left(R^{2}=0.9820\right)$. The detection limit was $0.5 \mu \mathrm{M}$. Compared to other peroxidases [27-30] (Table S1), 
the excellent sensitivity of Dh-A-H-E makes it well-suited for $\mathrm{H}_{2} \mathrm{O}_{2}$-mediated glucose detection. First, glucose was oxidized by glucose oxidase $\left(\mathrm{GO}_{\mathrm{x}}\right)$ in $\mathrm{NaH}_{2} \mathrm{PO}_{4}-\mathrm{Na}_{2} \mathrm{HPO}_{4}$ buffer (pH 7.0) for $30 \mathrm{~min}$ to produce $\mathrm{H}_{2} \mathrm{O}_{2}$. Then, Dh-A-H-E and TMB were directly added to this solution for another $5 \mathrm{~min}$. A typical glucose concentration-response curve was obtained and plotted in Figure $6 b$, with a linear regression equation of $\mathrm{A}=0.0073 \mathrm{C}+0.2553\left(R^{2}=0.9601\right)$. The linear range of glucose detection for the assay was between $10 \mu \mathrm{M}$ and $0.18 \mathrm{mM}$, with a detection limit of $2 \mu \mathrm{M}$. These parameters were more sensitive than other similar peroxidase mimic-based methods, as in [27-30] (detailed in Table S2).

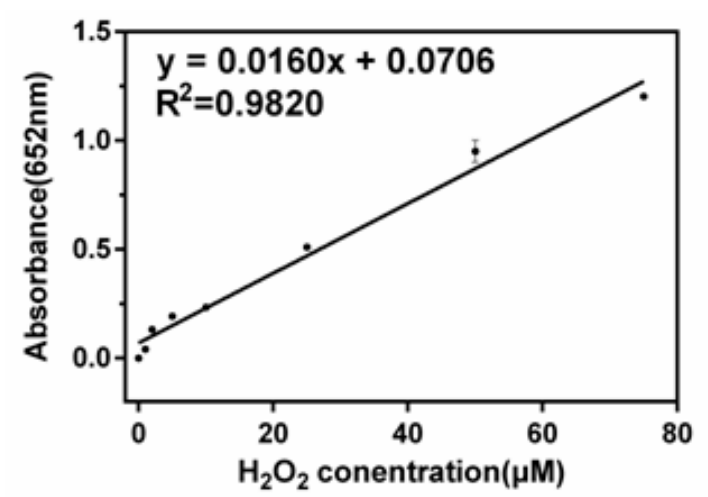

(a)

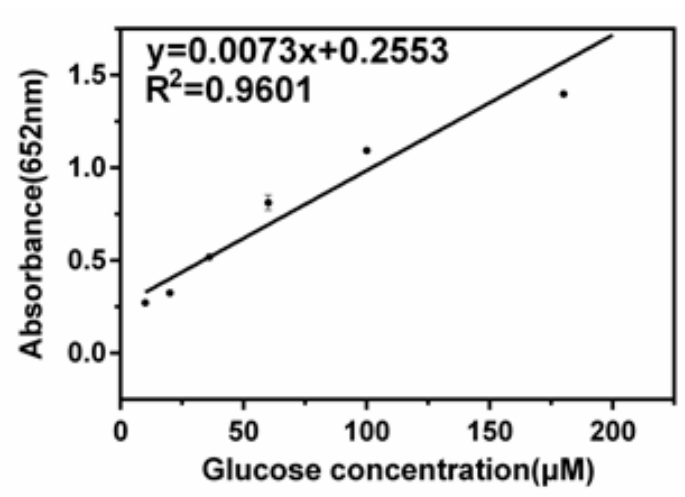

(b)

Figure 6. (a) Linear regression plot against different concentrations of $\mathrm{H}_{2} \mathrm{O}_{2} ;(\mathbf{b})$ linear regression plot against different concentrations of glucose. Experiments were performed in triplicate to obtain the mean value.

\section{Materials and Methods}

\subsection{Materials}

Rink amide resin, Fmoc amino acids, 1-hydroxybenzotriazole (HOBT), and benzotriazol-1-yloxytripyrrolidinophosphonium hexafluorophosphate (PYBOP) were purchased from Gl Biochem (Shanghai, China). N,N-Dimethylformamide (DMF) and dichloromethane (DCM) were purchased from Beijing Beihua Fine Chemicals Co., Ltd. (Beijing, China). Acetonitrile (HPLC grade, $\geq 99 \%$ ) was purchased from Oceanpak Alexative Chemicals Co., Ltd. (Gothenburg, Sweden). TMB, $\mathrm{H}_{2} \mathrm{O}_{2}$ (30\%), and glucose oxidase $\left(\mathrm{GO}_{\mathrm{x}}, 200 \mathrm{U} / \mathrm{mg}\right)$ were purchased from Dalian Meilun Biotechnology Co., Ltd. (Dalian, China). Ultrapure water was prepared using an ultrapure water purification system (Sichuan, China).

\subsection{Synthesis of $D h-A-H-E$}

$\mathrm{Dh}-\mathrm{A}-\mathrm{H}-\mathrm{E}$ was synthesized using solid phase peptide synthesis technology. The reaction was carried out in a solid phase peptide reactor. Rink amide resin was swelled in the reactor for $1 \mathrm{~h}$ with DCM. The deprotection reagent was then added to the reactor in DMF. Then, a three-fold excess of the Fmoc group-protected amino acids, HOBT and PYBOP, and a six-fold excess of organic base were added to the reactor in DMF for $2 \mathrm{~h}$. Then, deuterohemin/HOBT/PYBOP/organic base/rink amide resin were added in the amount of substance ratio 0.8:1.5:1.2:2:1 to the reactor, in DCM, for at least $8 \mathrm{~h}$. The peptide was dried in a vacuum dryer. Trifluoroacetic acid was used to cleave the peptide from the resin. The crude peptide was purified by Reversed-phase high-performance liquid chromatography (RP-HPLC). Dh-A-H-E was analyzed by RP-HPLC at $387 \mathrm{~nm}$ (Figure S1) and identified by Time-of-flight mass spectrometry (TOF-MS) (Figure S2). The synthesized peptide, with a purity of more than $95 \%$, was obtained. 


\subsection{Standard Peroxidase Activity Assay of Dh-A-H-E}

The reaction was carried out in a $1 \mathrm{~mL}$ cuvette. $\mathrm{NaH}_{2} \mathrm{PO}_{4}-\mathrm{Na}_{2} \mathrm{HPO}_{4}$ buffer solution $(0.7 \mathrm{~mL}$, $0.1 \mathrm{M}, \mathrm{pH} 7.4)$, TMB $(0.1 \mathrm{~mL}, 10 \mathrm{mM})$, Dh-A-H-E $(0.1 \mathrm{~mL}, 10 \mu \mathrm{M})$, and $\mathrm{H}_{2} \mathrm{O}_{2}(0.1 \mathrm{~mL}, 5 \mathrm{mM})$ were added in order. The reaction was carried out at $25{ }^{\circ} \mathrm{C}$ for $5 \mathrm{~min}$. The oxidation product of TMB was detected with a UV-VIS recording spectrophotometer (UV-2501PC) at $652 \mathrm{~nm}$. Experiments were performed in triplicate to obtain the mean value.

\subsection{Optimizing the Reaction Conditions}

To investigate the effect of temperature, the reaction was carried out at different temperatures $\left(5,15,25,35,45,55,65\right.$, and $\left.75^{\circ} \mathrm{C}\right)$. Then, the peroxidase activity assay of Dh-A-H-E was measured according to the standard assay in Section 3.3.

To investigate the effect of $\mathrm{pH}$, the reaction was carried out at different $\mathrm{pH} 1(4,5,6,7,7.2,7.4,7.6$, 8 and 9). Then, the peroxidase activity assay of Dh-A-H-E was measured according to the standard assay in Section 3.3.

\subsection{Kinetics of $D h-A-H-E$}

The kinetic assays were implemented at $25{ }^{\circ} \mathrm{C}$ in $1 \mathrm{~mL} \mathrm{NaH} \mathrm{PO}_{4}-\mathrm{Na}_{2} \mathrm{HPO}_{4}$ buffer solution $(0.1 \mathrm{M}, \mathrm{pH} 7.4)$, containing $100 \mu \mathrm{L}$ Dh-A-H-E $(10 \mu \mathrm{M})$ as a peroxidase in the presence of $\mathrm{H}_{2} \mathrm{O}_{2}$ and TMB. The kinetic constant of Dh-A-H-E with $\mathrm{H}_{2} \mathrm{O}_{2}$ as a substrate was obtained by adding a certain concentration $(2.0 \mathrm{mM})$ of TMB and different concentrations $(0.1,0.2,0.4,0.5,0.6,0.8$ and $1.0 \mathrm{mM})$ of $\mathrm{H}_{2} \mathrm{O}_{2}$. The kinetic constant of Dh-A-H-E with TMB as a substrate was obtained by adding a certain concentration $(1.0 \mathrm{mM})$ of $\mathrm{H}_{2} \mathrm{O}_{2}$ and different concentrations $(0.05,0.1,0.2,0.4,0.5,0.6,0.8,1.0,1.2$ and $1.5 \mathrm{mM})$ of TMB.

\subsection{Stability of $D h-A-H-E$}

The stability was tested in this study. Dh-A-H-E was incubated at different $\mathrm{pH}(4.4,5.4,6.4,7.4$, 8.4, and 9.4), temperatures $\left(5,15,25,35,45,55,65\right.$, and $\left.75^{\circ} \mathrm{C}\right)$, and in different organic solvents (DMSO, acetone, and acetonitrile) for $2 \mathrm{~h}$. Then, the residual activity was measured according to the standard assay in Section 3.3.

\subsection{Detection of the Trace Concentration of $\mathrm{H}_{2} \mathrm{O}_{2}$ and Glucose Using Dh-A-H-E}

First, glucose oxidase ( $\left.\mathrm{GO}_{x}, 20 \mu \mathrm{L}, 1.0 \mathrm{mg} / \mathrm{mL}\right), 20 \mu \mathrm{L}$ of glucose at different concentrations, and $\mathrm{NaH}_{2} \mathrm{PO}_{4}-\mathrm{Na}_{2} \mathrm{HPO}_{4}$ buffer $(160 \mu \mathrm{L}, 0.1 \mathrm{M}, \mathrm{pH} 7.0)$ were mixed and incubated at $37^{\circ} \mathrm{C}$ for $30 \mathrm{~min}$. Then, $\mathrm{NaH}_{2} \mathrm{PO}_{4}-\mathrm{Na}_{2} \mathrm{HPO}_{4}$ buffer $(600 \mu \mathrm{L}, 0.1 \mathrm{M}, \mathrm{pH} 7.4)$, TMB $(100 \mu \mathrm{L}, 10 \mathrm{mM})$, and Dh-A-H-E $(100 \mu \mathrm{L}, 10 \mu \mathrm{M})$ were added to the above solution together. The mixture was incubated at $25^{\circ} \mathrm{C}$ for 5 min, and the absorbance was recorded at $652 \mathrm{~nm}$.

\section{Conclusions}

In this study, we reported on the synthesis of a novel mimetic peroxidase, Dh-A-H-E. Dh-A-H-E can be easily synthesized using solid phase peptide synthesis technology. Its high peroxidase activity towards TMB and its excellent stability in a range of harsh environmental conditions indicates that $\mathrm{Dh}-\mathrm{A}-\mathrm{H}-\mathrm{E}$ is a valid mimetic peroxidase, and that its properties make it ideal in industrial and medical testing applications. 
Supplementary Materials: The following are available online at http://www.mdpi.com/2073-4344/9/2/168/s1. Figure S1: RP-HPLC of Dh-A-H-E; Figure S2: TOF-MS of Dh-A-H-E; Table S1: Comparison of the various mimetic peroxidases for $\mathrm{H}_{2} \mathrm{O}_{2}$ detection; Table S2: Comparison of various mimetic peroxidases for glucose detection.

Author Contributions: Conceptualization, L.W. and Z.W.; methodology, Y.Y.; software, Y.Y.; J.X., and Z.Z.; validation, J.X., Y.Y. and Z.Z.; formal analysis, H.L., K.W. and Y.Y.; investigation, Y.Y.; resources, Z.Z.; data curation, Y.Y.; writing—original draft preparation, Y.Y.; writing—review and editing, Z.W. and L.W.

Funding: This research was funded by the Special Project for Health from Jilin Province (No. 2018SCZWSZX-037).

Conflicts of Interest: The authors declare no conflict of interest.

\section{References}

1. Veitch, N.C. Horseradish peroxidase: A modern view of a classic enzyme. Phytochemistry 2004, 65, 249-259. [CrossRef]

2. Sun, H.; Jiao, X.; Han, Y.; Jiang, Z.; Chen, D. Synthesis of $\mathrm{Fe}_{3} \mathrm{O}_{4}-\mathrm{Au}$ nanocomposites with enhanced peroxidase-like activity. Eur. J. Inorg. Chem. 2013, 1, 109-114. [CrossRef]

3. Wang, M.; Bao, W.; Wang, J. A green approach to the synthesis of novel "Desert rose stone"-Like nanobiocatalytic system with excellent enzyme activity and stability. Sci. Rep. 2014, 4, 6606. [CrossRef] [PubMed]

4. Matsumoto, K.; Takahashi, H.; Miyake, Y. Convenient synthesis of neurotrophic americanol A and isoamericanol A by HRP catalyzed oxidative coupling of caffeic acid. Tetrahedron Lett. 1999, 40, 3185-3186. [CrossRef]

5. Lin, Y.; Liang, M.; Lin, Y. Specifically and reversibly immobilizing proteins/enzymes to nitriolotriacetic-acid-modified mesoporous silicas through histidine tags for purification or catalysis. Chem. Eur. J. 2011, 17, 13059-13067. [CrossRef] [PubMed]

6. Kobayashi, S.; Nakano, M.; Kimura, T. On the mechanism of the peroxidase-catalyzed oxygen-transfer reaction. Biochemistry 1987, 26, 5019-5022. [CrossRef] [PubMed]

7. Mu, J.; Zhang, L.; Zhao, M.; Wang, Y. $\mathrm{Co}_{3} \mathrm{O}_{4}$ nanoparticles as an efficient catalase mimic: Properties, mechanism and its electrocatalytic sensing application for hydrogen peroxide. J. Mol. Catal. A Chem. 2013, 378, 30-37. [CrossRef]

8. Liu, Y.; Liu, X.; Guo, Z.; Hu, Z.; Xue, Z.; Lu, X. Horseradish peroxidase supported on porous graphene as a novel sensing platform for detection of hydrogen peroxide in living cells sensitively. Biosens. Bioelectron. 2017, 87, 101-107. [CrossRef] [PubMed]

9. Yang, Y.; Shen, D.; Long, Y.; Xie, Z.; Zheng, H. Intrinsic of peroxidase-like activity of ficin. Sci. Rep. 2017, 7, 43141. [CrossRef]

10. Liu, L.; Shi, Y.; Yang, Y.; Li, M.; Long, Y.; Huang, Y.; Zheng, H. Fluorescein as an artificial enzyme to mimic peroxidase. Chem. Commun. 2016, 52, 13912-13915. [CrossRef]

11. Wang, Q.; Ma, K.; Yu, Z.; Ding, J.; Hu, Q.; Liu, Q.; Sun, H.; Wen, D.; Liu, Q.; Kong, J. The peroxidase-like catalytic activity of ferrocene and its application in the biomimetic synthesis of microsphere polyaniline. New J. Chem. 2018, 42, 13536-13540. [CrossRef]

12. Xia, X.; Long, Y.; Wang, J. Glucose oxidase-functionalized fluorescent gold nanoclusters as probes for glucose. Anal. Chim. Acta 2013, 772, 81-86. [CrossRef] [PubMed]

13. Ghavidel Hajiagha, N.; Mahmoudi, A.; Sazegar, M.R.; Pouramini, M.M. Synthesis of cobalt-modified MSN as a model enzyme: Evaluation of the peroxidatic performance. Microporous Mesoporous Mater. 2019, 274, 43-53. [CrossRef]

14. Kalaivani, G.; Sivanesan, A.; Kannan, A.; Sevvel, R. Generating monomeric 5-coordinated microperoxidase-11 using carboxylic acid functionalized silver nanoparticles: A surface-enhanced resonance Raman scattering analysis. Colloids Surf. B 2016, 146, 722-730. [CrossRef] [PubMed]

15. Lin, Y.W. The broad diversity of heme-protein cross-links: An overview. Biochim. Biophys. Acta 2015, 1584, 844-859. [CrossRef] [PubMed]

16. Ascenzi, P.; Leboffe, L.; Santucci, R.; Coletta, M. Ferric microperoxidase-11 catalyzes peroxynitrite isomerization. J. Inorg. Biochem. 2015, 144, 56-61. [CrossRef]

17. Guan, S.; Li, P.; Luo, J. A deuterohemin peptide extends lifespan and increases stress resistance in Caenorhabditis elegans. Free Radic. Res. 2010, 44, 813-820. [CrossRef] 
18. Casella, L.; Gullotti, M.; Monzani, E. Biomimetic oxidation catalysis by iron (III) deuteroporpbyrin carrying a deca-L-alanine peptide chain. Rend. Lincei 1991, 2, 201-212. [CrossRef]

19. Casella, L.; Monzani, E.; Fantucci, P. Axial imidazole distortion effects on the catalytic and binding properties of chelated deuterohemin complexes. Inorg. Chem. 1996, 35, 439-444. [CrossRef]

20. Guo, J.; Wang, Y.; Zhao, M. 3D flower-like ferrous(II) phosphate nanostructures as peroxidase mimetics for sensitive colorimetric detection of hydrogen peroxide and glucose at nanomolar level. Talanta 2018, 182, 230-240. [CrossRef]

21. Pang, Y.; Huang, Z.; Yang, Y.; Long, Y.; Zheng, H. Colorimetric detection of glucose based on ficin with peroxidase-like activity. Spectrochim. Acta Part A 2018, 189, 510-515. [CrossRef] [PubMed]

22. Zhang, Y.; Zhou, Z.; Wen, F.; Tan, J.; Peng, T.; Luo, B.; Wang, H.; Yin, S. A flower-like $\mathrm{MoS}_{2}$-decorated $\mathrm{MgFe}_{2} \mathrm{O}_{4}$ nanocomposite: Mimicking peroxidase and colorimetric detection of $\mathrm{H}_{2} \mathrm{O}_{2}$ and glucose. Sens. Actuators B 2018, 275, 155-162. [CrossRef]

23. Gao, Y.; Wu, K.; Li, H.; Chen, W.; Fu, M.; Yue, K.; Zhu, X.; Liu, Q. Glutathione detection based on peroxidase-like activity of $\mathrm{Co}_{3} \mathrm{O}_{4}$-Montmorillonite nanocomposites. Sens. Actuators B 2018, 273, 1635-1639. [CrossRef]

24. Shi, Y.; Liu, L.; Yu, Y.; Long, Y.; Zheng, H. Acidic amino acids: A new-type of enzyme mimics with application to biosensing and evaluating of antioxidant behavior. Spectrochim. Acta Part A 2018, 201, 367-375. [CrossRef]

25. Savic, S.; Vojinovic, K.; Milenkovic, S.; Smelcerovic, A.; Lamshoeft, M.; Petronijevic, Z. Enzymatic oxidation of rutin by horseradish peroxidase: Kinetic mechanism and identification of a dimeric product by LC-Orbitrap mass spectrometry. Food Chem. 2013, 141, 4194-4199. [CrossRef] [PubMed]

26. Li, Y.; Li, T.; Chen, W.; Song, Y. $\mathrm{Co}_{4} \mathrm{~N}$ Nanowires: Noble-Metal-Free Peroxidase Mimetic with Excellent Saltand Temperature-Resistant Abilities. ACS Appl. Mater. Interfaces 2017, 9, 29881-29888. [CrossRef] [PubMed]

27. Jin, L.; Shang, L.; Guo, S.; Fang, Y.; Wen, D.; Wang, L.; Yin, J.; Dong, S. Biomolecule-stabilized Au nanoclusters as a fluorescence probe for sensitive detection of glucose. Biosens. Bioelectron. 2011, 26, 1965-1969. [CrossRef] [PubMed]

28. Dong, Y.; Zhang, H.; Rahman, Z.U.; Su, L.; Chen, X.; Hu, J.; Chen X., G. Graphene Oxide-Fe ${ }_{3} \mathrm{O}_{4} \mathrm{Magnetic}$ Nanocomposites with peroxidase-Like Activity for colorimetric detection of glucose. Nanoscale 2012, 4, 3969-3976. [CrossRef]

29. Li, M.; Liu, L.; Shi, Y.; Yang, Y.; Zheng, H.; Long, Y. Dichlorofluorescein as a peroxidase mimic and its application to glucose detection. New J. Chem. 2017, 41, 7578-7582. [CrossRef]

30. Malvi, B.; Panda, C.; Dhar, B.B.; Gupta, S.S. One pot glucose detection by [Fe ${ }^{\mathrm{III}}$ (biuret-amide)] immobilized on mesoporous silica nanoparticles: An efficient HRP mimic. Chem. Commun. 2012, 48, 5289-5291. [CrossRef] 